\title{
Recolonization of Zostera marina following destruction caused by a red tide algal bloom: the role of new shoot recruitment from seed banks
}

\author{
Kun-Seop Lee*, Jung-Im Park, Young Kyun Kim, Sang Rul Park, Jong-Hyeob Kim \\ Department of Biology, Pusan National University, Pusan 609-735, Korea
}

\begin{abstract}
Harmful microalgal blooms such as red-tide or brown-tide events lead to abrupt light reductions and consequently cause immediate damage to seagrass beds. Because red tide algal blooms usually occur unexpectedly, seagrass responses to the microalgal blooms have rarely been documented. A red tide caused by a dense bloom of Heterosigma akashiwo, a noxious red-tide-causing alga of temperate and subtropical waters, occurred at a study site on the south coast of Korea in late May 2002. Because the red-tide event occurred on an eelgrass bed where seagrass monitoring was being conducted, pre-event conditions were well documented. Nearly all eelgrass shoots disappeared rapidly because of the reduction in light caused by the algal bloom. Additionally, a thick layer of mucilaginous material secreted from algal cysts suffocated eelgrass plants for weeks, directly causing eelgrass death. Eelgrass seedlings were found in the die-off area from December $2002 ;<1 \mathrm{yr}$ after its destruction, the site was completely re-established by seedling recruitment via germination from the seed bank. Seedling mortality was very low. Seedlings grew exponentially during the spring, and their fast growth also contributed to rapid eelgrass recolonization. During the second year of recolonization, asexual reproduction through lateral shoot production by rhizome elongation and branching played the main role in the persistence and growth of the eelgrass bed. Seed density in the seed bank varied seasonally, increasing to a maximum after seed release and decreasing to nearly zero after seed germination. Many more seedlings were found and nearly all seedlings established successfully in the first year after the bloom, when no adult eelgrass shoots were observed, suggesting significant effects of shoot density on rates of seed germination and seedling establishment. This was a unique opportunity to examine eelgrass responses to dense microalgal blooms, which provided valuable information on the die-off process caused by red tide and the natural recolonization of seagrass after its destruction.
\end{abstract}

KEY WORDS: Recolonization · Red tide algal bloom $\cdot$ Eelgrass $\cdot$ Zostera marina $\cdot$ Die-off $\cdot$ Seed bank - Seedling Resale or republication not permitted without written consent of the publisher

\section{INTRODUCTION}

Seagrasses are distinct and vital components of coastal and estuarine ecosystems, but significant declines of these habitats because of natural and anthropogenic disturbances have been reported from many parts of the world (Orth \& Moore 1983a, Cambridge \& McComb 1984, Short \& Wyllie-Echeverria 1996). The main causes of seagrass declines are related to reductions in water quality and increased turbidity. Large storms, floods, and microalgal blooms induced naturally or by anthropogenic nutrient loading can increase levels of suspended solids or chlorophyll concentrations and consequently lead to a reduction in underwater irradiance, which causes declines in seagrass coverage (Orth \& Moore 1983a, Goldsborough \& Kemp 1988, Dennison et al. 1993, Onuf 1994).

Because red and/or brown tides caused by dense phytoplankton blooms can bring instantaneous and dramatic underwater light reductions, they will lead to immediate damage to seagrass beds. However, seagrass responses to harmful algal blooms have rarely 
been reported (Onuf 1996). Red tide algal blooms usually occur unexpectedly; accordingly, seagrass conditions both before and after the occurrence of blooms have seldom been documented. On the coasts of Korea, red tide algal blooms occur frequently during the summer period; the frequency of bloom events has been increasing from 5 to 40 times $\mathrm{yr}^{-1}$ during the 1980s to 30 to 120 times $\mathrm{yr}^{-1}$ during the 1990s (Kim et al. 2000). At a study site on the south coast of Korea, where monitoring of seagrass beds was in progress, a red-tide event caused by a very dense bloom of Heterosigma akashiwo occurred in late May 2002 and lasted for about $2 \mathrm{wk}$. The seagrass bed and abiotic factors, such as underwater light and nutrient conditions, had been monitored before the bloom event. The physiological responses of seagrasses to underwater light reductions are usually examined using artificial shading experiments (Dennison \& Alberte 1982, Lee \& Dunton 1997, Ruiz \& Romero 2001). Therefore, this study allowed a unique opportunity to examine seagrass responses to red tide algal blooms and to monitor the rapid decline in seagrass habitat caused by the bloom. It also provided valuable information for understanding seagrass declines caused by light reductions resulting from natural phenomena.

Seagrass meadows expand in coverage, usually through asexual vegetative growth and ramification (Tomlinson 1974). However, new shoot recruitment through the germination of seeds transported from neighboring areas and seed pools in sediments would play an important role in the persistence of seagrass meadows when all seagrass plants have died during an unfavorable season or because of natural or anthropogenic disturbances (Peterken \& Conacher 1997, Cabello-Pasini et al. 2002, Plus et al. 2003, Olesen et al. 2004, Greve et al. 2005). Thus, sexual reproduction via seedling recruitment should be examined to understand the recovery processes of degraded seagrass beds with few seagrass shoots. Eelgrass seed production has been found to be highly variable, ranging from 200 to about 80000 seeds $\mathrm{m}^{-2}$ (Hootsmans et al. 1987, Keddy 1987, Harrison 1993, Fishman \& Orth 1996). A large proportion of seagrass seeds may be lost to predation, disease, and transport to unsuitable sites (Wigand \& Churchill 1988, Fishman \& Orth 1996, Inglis 2000, Nakaoka 2002), causing discrepancies between seed production and seedling abundance.

The eelgrass Zostera marina is the most abundant seagrass species on the coasts of the Korean peninsula (Shin \& Choi 1998, Lee \& Lee 2003). New eelgrass shoots are created as lateral shoots by the branching of rhizomes during spring, and the expansion of eelgrass meadows coincides with the creation of new shoots in spring on the coast of Korea (Lee et al. 2005). Repro- ductive shoots occur between March and June, and seeds are released from May in this area (Lee et al. 2005). At the study site, nearly all eelgrass plants disappeared because of the red tide algal bloom during late May and early June. Because seedlings were observed in most eelgrass beds off the coast of Korea during early spring, we hypothesized that the area of eelgrass die-off caused by the red tide algal bloom would recover through seedling recruitment from the germination of seeds in sediments.

We examined the eelgrass decline caused by the red tide algal bloom in relation to shoot density, biomass, and continuous measurements of underwater irradiance before and after the red-tide event. We also examined the recolonization of the die-off area to determine the reestablishment processes in disturbed areas. Additionally, we investigated seed production, seed density in the seed bank, and seedling establishment to examine the role of sexual reproduction in the recolonization of the area disturbed by the red tide algal bloom.

\section{MATERIALS AND METHODS}

Study site. The study site was located in Jindong Bay on the south coast of the Korean peninsula (Fig. 1). Zostera marina is distributed in relatively shallow areas, whereas $Z$. caulescens is usually distributed in water depths of about $10 \mathrm{~m}$. Several spatially separated eelgrass beds are distributed in Jindong Bay at depths of 1 to $5 \mathrm{~m}$. This study was conducted on a monotypic meadow of $Z$. marina, which is about $0.1 \mathrm{~km}^{2}$ in size, at an average water depth of about $2.5 \mathrm{~m}$. Eelgrass shoot density and biomass were monitored from March 2002 to August 2004. Shoot weight of seedlings was monitored from December 2002 to August 2003.

Underwater irradiance and nutrients in the water column and sediments. Underwater photon flux density (PFD) at the seagrass canopy level was monitored using a HOBO data logger (Onset Computer), encased in a waterproof underwater housing. Measurements were taken every 15 min before and after the red-tide event. The underwater sensor was cleaned regularly to minimize fouling. Light intensity (lumens $\mathrm{ft}^{-2}$ ), measured using the HOBO data logger, was converted to PFD ( $\mu$ mol photons $\mathrm{m}^{-2} \mathrm{~s}^{-1}$ ) using concurrent quantum measurements for about $50 \mathrm{~d}$, using an LI-1400 data logger and an LI-193SA spherical quantum sensor (LI-COR). A regression analysis was performed to convert the light intensity measured using the HOBO data logger to PFD. HOBO measurements and PFD exhibited a relatively strong correlation $\left(\mathrm{r}^{2}=0.84\right)$. 
To determine water column inorganic nutrient concentrations, 4 replicate surface water samples were collected monthly from April 2002 to August 2004. Dissolved inorganic nitrogen $\left(\mathrm{NH}_{4}{ }^{+}, \mathrm{NO}_{3}{ }^{-}+\mathrm{NO}_{2}{ }^{-}\right)$and phosphate $\left(\mathrm{PO}_{4}{ }^{3-}\right)$ concentrations were determined using standard colorimetric techniques following the methods of Parsons et al. (1984). To determine nutrient concentrations in sediment pore water, 6 to 10 replicate sediment samples were collected randomly to a sediment depth of about $15 \mathrm{~cm}$ using a sediment corer. Samples were placed on ice and frozen pending laboratory analyses. Sediment pore water was obtained by centrifugation $(5000 \times g$ for $15 \mathrm{~min}$ ) and then diluted with low-nutrient seawater for determination of pore-water nutrient concentrations.

Biological measurements. Shoot density and biomass were measured monthly from March 2002 to August 2004. Above- and below-ground tissues inside randomly selected quadrats $(0.35 \times 0.35 \mathrm{~m}$; $\mathrm{n}=4$ to 6 ) were collected for shoot density and biomass measurements. Shoots were separated into seedlings and vegetative and reproductive shoots and then counted to estimate shoot density. Collected tissues were thoroughly cleaned of epiphytes and sediments, separated into above- (blade + sheath) and below-ground (root + rhizome) tissues, and dried at $60^{\circ} \mathrm{C}$ to constant weight. Samples were weighed, and biomass was converted to per-unit-area estimates ( $g$ dry wt $\mathrm{m}^{-2}$ ). Then, 10 to 50 seedlings were collected individually to measure seedling weight during the first year after the red-tide event. Seedlings were separated into above- and belowground tissues and dried at $60^{\circ} \mathrm{C}$ to constant weight to measure individual seedling weight.

The density of reproductive shoots, number of inflorescences per shoot, and number of seeds per inflorescence were determined to estimate the potential seed production. Maximum values of reproductive shoot density, average number of inflorescences per shoot and average number of seeds per inflorescence in the year were used for calculation of the seed production. The potential seed production per shoot was estimated by multiplying the number of inflorescences per shoot by the number of seeds per inflorescence. Seed production per unit area was determined by multiplying the potential seed production per shoot by the reproductive shoot density. To estimate the seed density in the seed bank, 6 randomly distributed core samples (20 $\mathrm{cm}$ in diameter) were taken monthly to a sediment depth of about $10 \mathrm{~cm}$. The core samples were sieved through $1 \mathrm{~mm}$ mesh screen in the field to remove sediments, and then the number of seeds was counted under a magnifier in the laboratory.
Statistical analyses. All values are reported as means $( \pm \mathrm{SE})$. Statistical analyses were performed on a microcomputer using a general linear model procedure (SAS). Data were tested for normality and homogeneity of variance to meet the assumptions of parametric statistics. Differences in the environmental factors and biological characteristics of Zostera marina between sampling times were tested for significance using 1-way ANOVA. When significant differences were detected, we used Tukey multiple comparisons to determine where the significant differences lay.

\section{RESULTS}

\section{Red-tide event}

The red tide algal bloom, caused by high densities (about 15000 cells $\mathrm{ml}^{-1}$ ) of the alga Heterosigma akashiwo, occurred for about 2 wk in late May and early June 2002, and negatively affected eelgrass beds in Jindong Bay on the south coast of Korea. Underwater irradiance was dramatically reduced during the algal bloom (Fig. 2). Daily maximum underwater PFDs were usually $>200 \mu \mathrm{mol}$ photons $\mathrm{m}^{-2} \mathrm{~s}^{-1}$ and reached about $900 \mu \mathrm{mol}$ photons $\mathrm{m}^{-2} \mathrm{~s}^{-1}$ before the bloom, but were usually $<50 \mu \mathrm{mol}$ photons $\mathrm{m}^{-2} \mathrm{~s}^{-1}$ during the bloom event from 24 May to 6 June 2002 (Fig. 2).

Heterosigma akashiwo sank to the bottom when the bloom decayed, and the cysts secreted mucus. The Zostera marina meadow was covered with a mucus layer about 0.3 to $1.0 \mathrm{~m}$ thick, and eelgrass plants and benthic animals were suffocated (Fig. 3). The mucilaginous matrix lasted about $2 \mathrm{wk}$ on the sediments of the study area. All eelgrass shoots disappeared from 


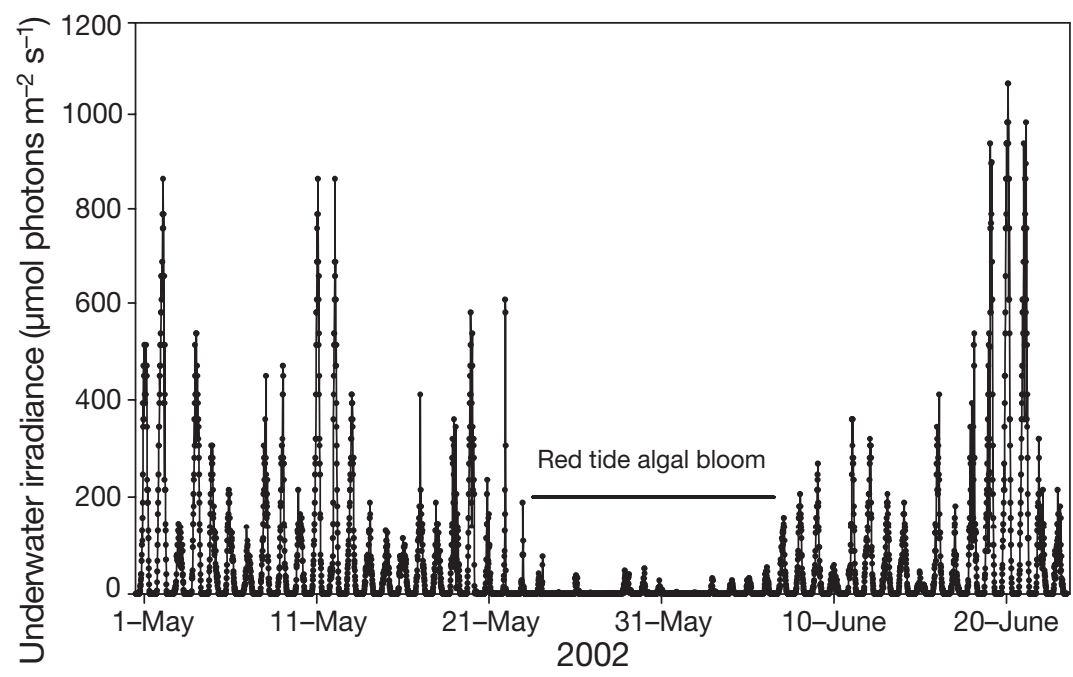

Fig. 2. Underwater photon flux density ( $\mu$ mol photons $\mathrm{m}^{-2} \mathrm{~s}^{-1}$ ) measured at the eelgrass Zostera marina canopy level before, during, and after the red tide algal bloom event. According to underwater light measurements, the algal bloom event occurred from 24 May to 6 June 2002
However, all eelgrass shoots disappeared after the bloom event in May and June 2002, and no eelgrass shoots were subsequently observed in the study plot until December 2002 (Fig. 6A). Seedlings appeared from December 2002 through the germination of seeds in the sediments, which were produced in spring 2002 before the bloom event, and seedling density reached about 100 shoots $\mathrm{m}^{-2}$ in January 2003. This shoot density was sustained during spring and early summer 2003, and then decreased to about 30 shoots $\mathrm{m}^{-2}$ in fall 2003 (Fig. 6A). Shoot density increased again through sexual and asexual reproduction, i.e. germination of seeds in seed banks and lateral shoot production, respectively, during winter and spring 2004, and reached over 200 shoots $\mathrm{m}^{-2}$ in April 2004 (Fig. 6A).

the site plot, and dead benthic animals were observed on the sediment surface after the redtide event.

\section{Nutrient concentrations in the water column and sediments}

Water column $\mathrm{NH}_{4}{ }^{+}$and $\mathrm{NO}_{3}{ }^{-}+\mathrm{NO}_{2}^{-}$concentrations varied significantly with sampling time ( $p<0.001)$, but were not largely affected by the bloom event (Fig. 4A,B). Water column dissolved inorganic nitrogen concentrations showed peaks after rain events and freshwater inflows. Water column $\mathrm{PO}_{4}{ }^{3-}$ concentrations were usually $<1.0$ $\mu \mathrm{M}$, but the concentration was about $19 \mu \mathrm{M}$ during the bloom (Fig. 4C).

In contrast to the water column nutrients, sediment pore-water nutrient concentrations increased significantly during the bloom event ( $\mathrm{p}<$ 0.001) (Fig. 5). Sediment $\mathrm{NH}_{4}{ }^{+}$concentrations were usually $<150 \mu \mathrm{M}$, but increased to $>1000 \mu \mathrm{M}$ during the algal bloom, and then gradually decreased to normal concentrations after the bloom event (Fig. 5A). Pore-water $\mathrm{NO}_{3}^{-}+\mathrm{NO}_{2}{ }^{-}$ and $\mathrm{PO}_{4}{ }^{3-}$ concentrations also exhibited peaks during the bloom event (Fig. 5B,C).

\section{Shoot density and biomass}

Prior to the harmful algal bloom, the total eelgrass shoot density increased from about 50 shoots $\mathrm{m}^{-2}$ in March to about 170 shoots $\mathrm{m}^{-2}$ in May 2002.
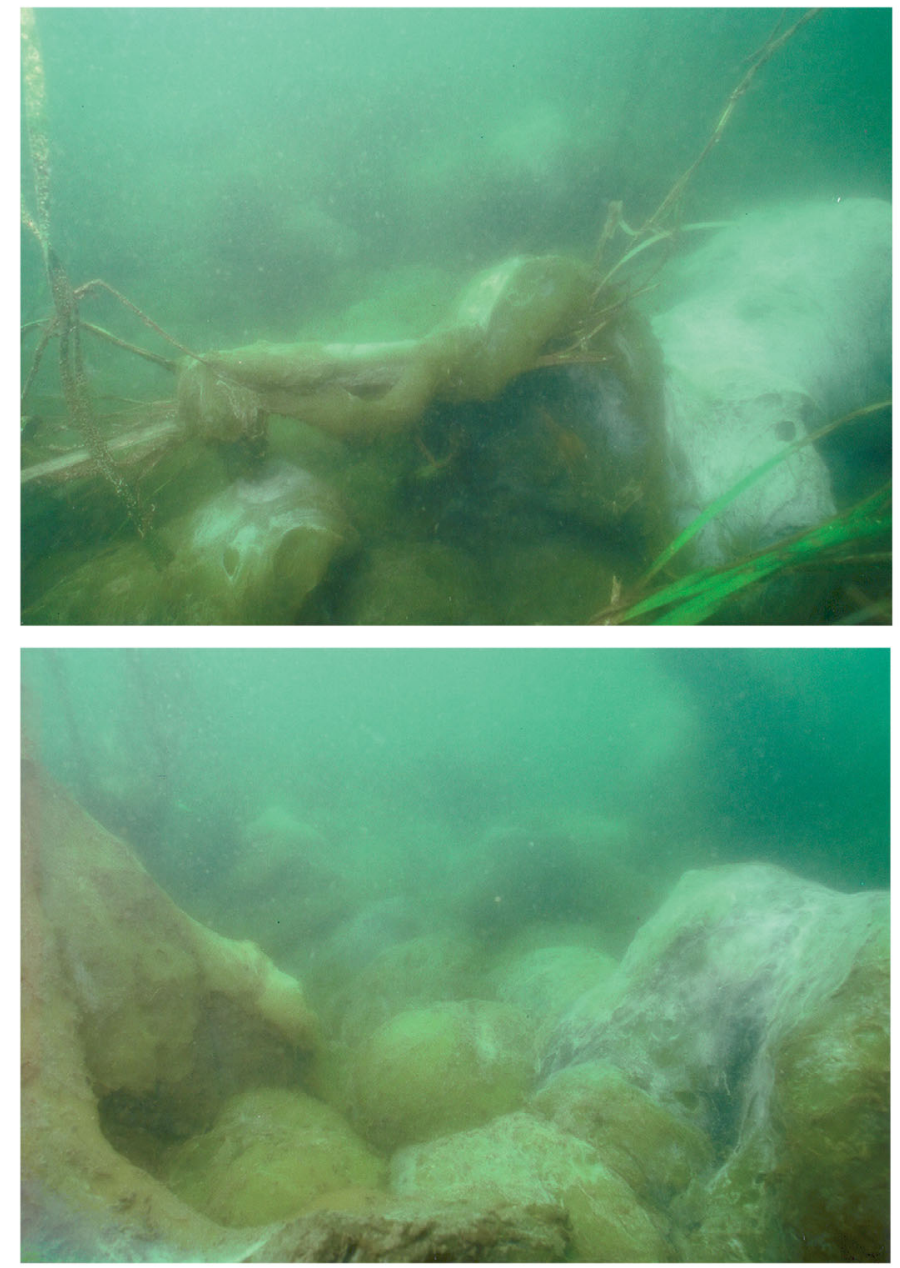

Fig. 3. Mucilaginous material secreted from cysts of the red tide alga Heterosigma akashiwo. A layer of mucus 0.3 to $1.0 \mathrm{~m}$ thick covered the eelgrass Zostera marina bed at the study site 

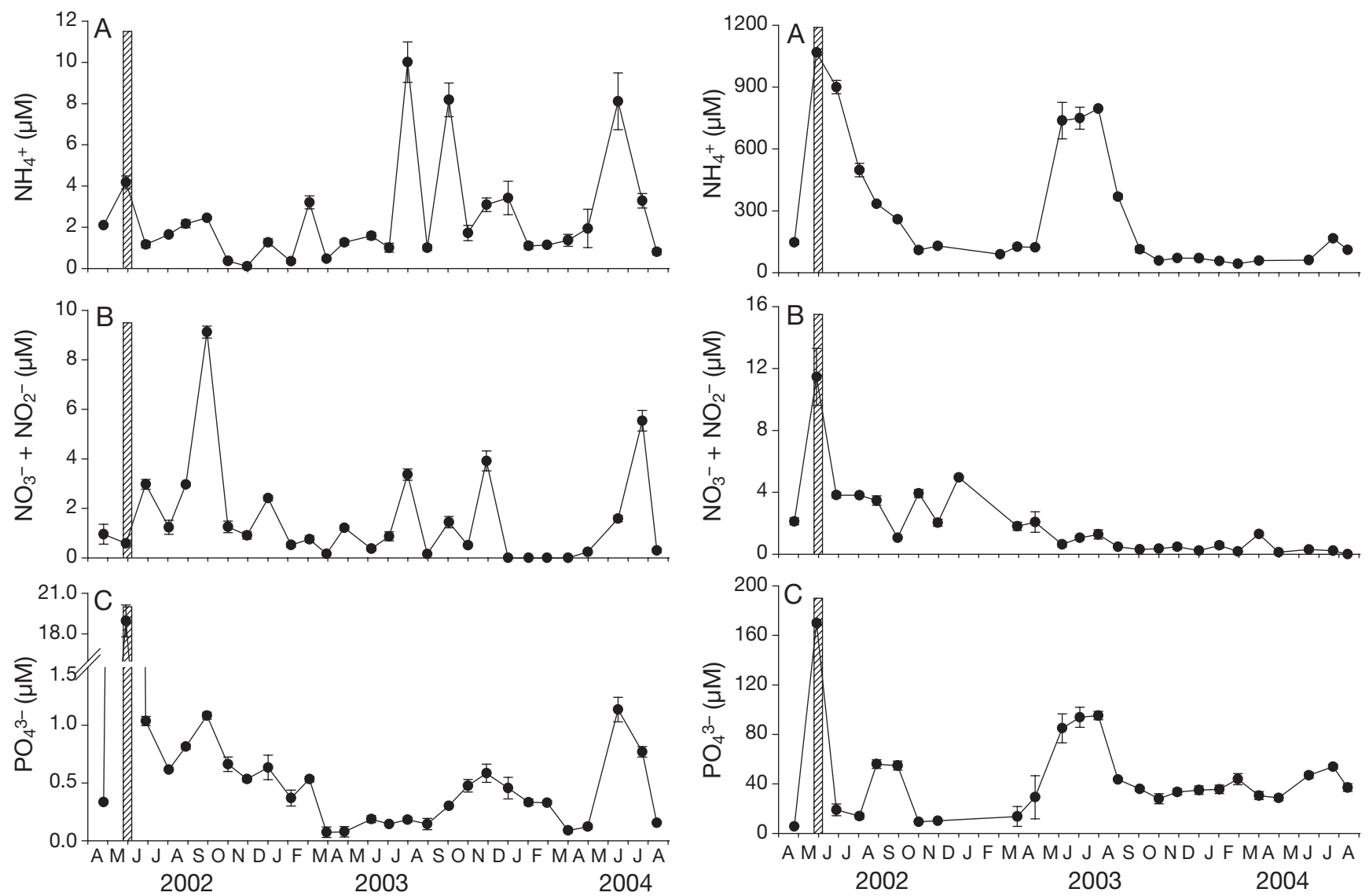

Fig. 4. Seasonal changes in nutrient concentrations (mean $\pm \mathrm{SE}$ ) in the water column in Jindong Bay on the south coast of Korea from April 2002 to August 2004: (A) $\mathrm{NH}_{4}{ }^{+}$, (B) $\mathrm{NO}_{3}{ }^{-}+$ $\mathrm{NO}_{2}{ }^{-}$, and $(\mathrm{C}) \mathrm{PO}_{4}{ }^{3-}$. Vertical bars indicate the period of the red tide algal bloom

Seasonal changes in total shoot density were closely correlated with variations in vegetative shoot density, which accounted for $>90 \%$ of the total density (Fig. 6A, B). Reproductive shoots appeared from February to July (Fig. 6C). In 2002, the year before the algal bloom event, the reproductive shoot density was highest during May (about 22 shoots $\mathrm{m}^{-2}$ ) and accounted for about $13 \%$ of the total shoot density, whereas the maximum reproductive shoot density in 2003, the first year of recolonization, was about 10 shoots $\mathrm{m}^{-2}$ in June, which accounted for about $10 \%$ of the total shoot density. In 2004, the density of reproductive shoots peaked in early April (45 shoots $\mathrm{m}^{-2}$ ) and accounted for about $20 \%$ of the total shoot density (Fig. 6C).

The ratio of seedlings to adult shoots in spring, when eelgrass meadows in the study site expanded their coverage via clonal growth, varied significantly before and after the bloom event $(p<0.001)$ (Table 1$)$. Adult shoots accounted for $77.4 \%$ of the total shoot density in spring 2002 before the bloom, whereas seedlings accounted for $100 \%$ of eelgrass shoots in

Fig. 5. Seasonal changes in sediment pore-water nutrient concentrations (mean \pm SE) in the eelgrass Zostera marina bed in Jindong Bay on the south coast of Korea from April 2002 to August 2004: (A) $\mathrm{NH}_{4}{ }^{+}$, (B) $\mathrm{NO}_{3}{ }^{-}+\mathrm{NO}_{2}{ }^{-}$, and (C) $\mathrm{PO}_{4}{ }^{3-}$. Vertical bars indicate the period of the red tide algal bloom

spring 2003, the first spring after the bloom. In spring 2004 and $2005,>90 \%$ of eelgrass plants were adult shoots (Table 1).

Total biomass increased from about $100 \mathrm{~g}$ dry wt $\mathrm{m}^{-2}$ in March to about $500 \mathrm{~g}$ dry wt $\mathrm{m}^{-2}$ in May 2002 before the eelgrass die-off by the harmful algal bloom, but all eelgrass plants died after the bloom (Fig. 7). During 2003 and 2004, after the re-establishment of the eelgrass bed by new shoot recruitment from the germination of seeds in sediments, aboveand below-ground biomass and total biomass reached levels recorded before the bloom and exhibited distinct seasonal variation. Total and aboveground biomass was highest in June and lowest throughout late summer and fall, whereas belowground biomass was highest in June 2003 and August 2004, and also lowest through late summer and fall (Fig. 7). During fall and winter, biomass decreased to $<10 \%$ of the maximum biomass, whereas shoot density decreased by only about 50 to $70 \%$ of the maximum density (Figs. $6 \& 7$ ). 



Fig. 6. Zostera marina. Seasonal variation in: (A) total shoot, (B) vegetative shoot, and (C) reproductive shoot density (mean $\pm \mathrm{SE}$ ) at the study site in Jindong Bay on the south coast of Korea from March 2002 to August 2004. All eelgrass shoots disappeared after the red tide algal bloom event in late May 2002, and new seedlings were found beginning in December 2002. Vertical bars indicate the period of the red tide algal bloom

\section{Seed bank and seedling growth}

Eelgrass seedlings that established after the disturbance caused by the bloom event grew rapidly during spring and reached the size of adult plants in late spring and early summer (Fig. 8). The weight of an entire seedling was about $0.012 \mathrm{~g}$ dry wt shoot $^{-1}$ in early December 2002 and increased exponentially during the spring (Fig. 8). Seedling weight reached a maximum of about $1.5 \mathrm{~g}$ dry wt shoot ${ }^{-1}$ in July. Aboveground tissues accounted for 80 to $90 \%$ of total seedling weight (Fig. 8).

Seed density in the seed bank exhibited distinct seasonal and interannual variations (Fig. 9). The number of seeds in sediments was highest in summer after the release of seeds from reproductive shoots, and few seeds were observed in spring after seed germination. The maximum seed density in sediments
Table 1. Zostera marina. Shoot density $(\mathrm{d} ;$ mean $\pm \mathrm{SE} ; \mathrm{n}=8$ to 16) of seedlings and adults at the study site in spring (March and April) when eelgrass meadows at the site expand in coverage via clonal growth. \%: proportion of the total number of shoots in that year

\begin{tabular}{|ccccccc}
\hline \multirow{2}{*}{ Year } & \multirow{2}{*}{ Adult } & \multicolumn{2}{c}{ Seedling } & & & \\
\cline { 3 - 3 } & $\mathrm{d}$ & $\%$ & & $\mathrm{~d}$ & $\%$ \\
\hline 2002 & $66.3 \pm 14.3$ & 77.4 & & $19.4 \pm 10.6$ & 22.6 \\
2003 & 0 & 0 & & $84.8 \pm 12.4$ & 100 \\
2004 & $174.5 \pm 20.1$ & 94.0 & & $11.2 \pm 4.1$ & 6.0 \\
2005 & $250.3 \pm 16.6$ & 92.0 & & $21.8 \pm 2.7$ & 8.0 \\
\hline
\end{tabular}

in 2003, the first year after the die-off, was about 200 seeds $\mathrm{m}^{-2}$ in August, whereas the maximum seed density in seed banks in 2004 and 2005 was about 850 seeds $\mathrm{m}^{-2}$ in September 2004 and about 1780 seeds $\mathrm{m}^{-2}$ in July 2005 (Fig. 9).

There was significant interannual variation in the maximum density of reproductive shoots and number of inflorescences per shoot $(p<0.05$ and $p<0.01$, respectively) (Table 2 ). The density of reproductive shoots and number of inflorescences per shoot were distinctly lower in 2003 than in 2002, 2004, and 2005 because all shoots were seedlings $<1$ yr of age in 2003. The number of seeds per inflorescence, however, was not significantly different among sampling years ( $p=0.628$ ) (Table 2). Potential seed production in 2002 was about 5500 seeds $\mathrm{m}^{-2}$. Seed production clearly decreased to about 1300 seeds $\mathrm{m}^{-2}$ in 2003, and then increased to about 15900 and 25500 seeds $\mathrm{m}^{-2}$ in 2004 and 2005, respectively (Table 2).

\section{DISCUSSION}

\section{Eelgrass die-off caused by the red tide algal bloom}

Nearly all shoots of Zostera marina at the study site were killed by the red tide algal bloom event, but the degraded eelgrass bed completely recovered from the damage caused by the bloom through new shoot recruitment from seeds in the sediments. Eelgrass shoots disappeared because of severe light reductions during the bloom and suffocation by the thick layer of mucus secreted by the cysts of the red tide alga. Redtide events on the coasts of Korea usually occurred by the blooms of Heterosigma akashiwo, Prorocentrum minimum, or Cochlodinium polykrikoides, and lasted $>2$ wk (Kim 2005). Declines and losses of seagrass coverage because of decreased water quality and underwater light have been reported throughout the world (Orth \& Moore 1983a, Goldsborough \& Kemp 1988, Dennison et al. 1993, Onuf 1994). Increased water turbidity caused by natural microalgal blooms or 


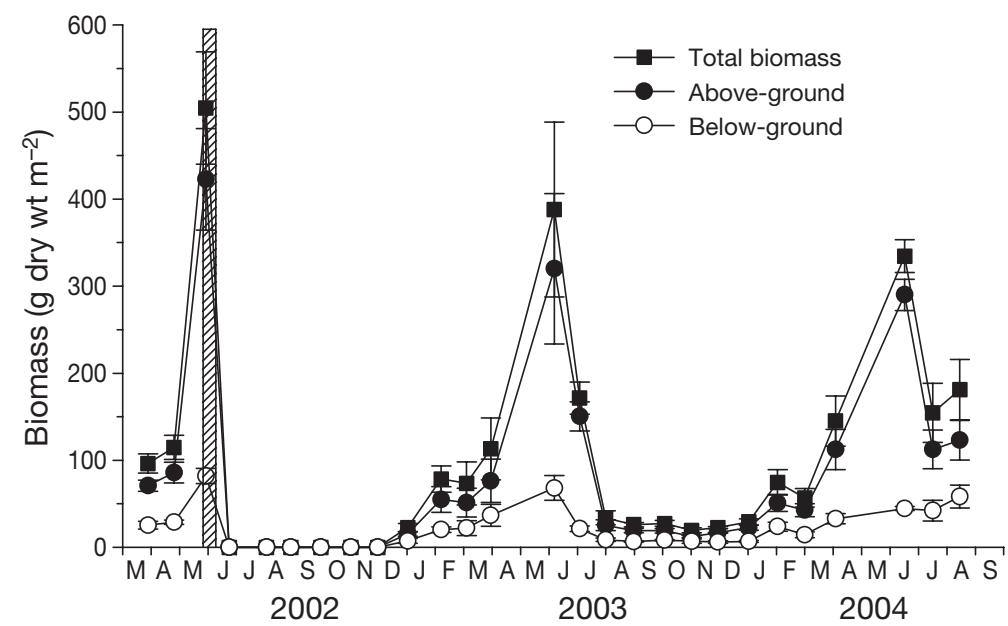

Fig. 7. Zostera marina. Seasonal variation in above-ground, below-ground, and total biomass (mean $\pm \mathrm{SE}$ ) at the study site in Jindong Bay on the south coast of Korea from March 2002 to August 2004. Vertical bar indicates the period of the red tide algal bloom

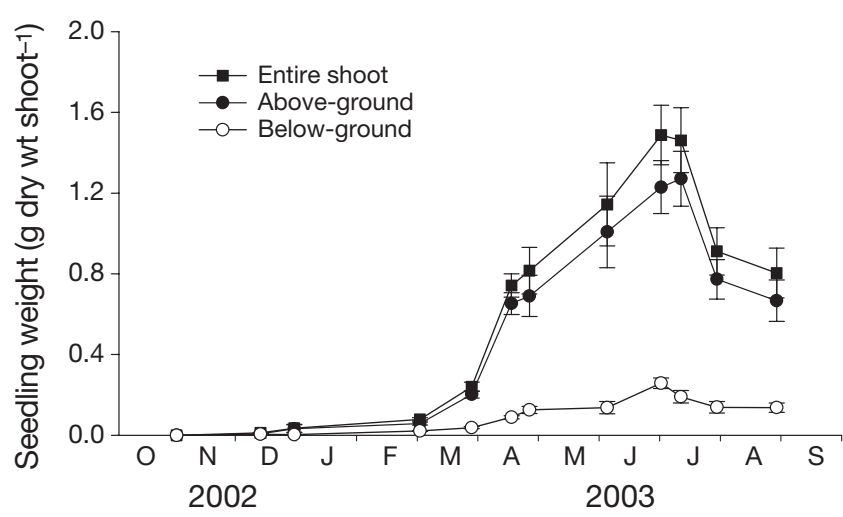

Fig. 8. Zostera marina. Temporal changes in per-seedling weight (mean \pm SE) from December 2002 to August 2003

anthropogenic nutrient loading is a major cause of seagrass declines (Onuf 1996, Short \& Burdick 1996). Despite the correlation between seagrass decline and cultural eutrophication, few studies have examined rapid seagrass die-off caused by red tide algal blooms.

Underwater irradiance was severely reduced during the bloom, which probably caused considerable damage to the eelgrass. About $80 \%$ of eelgrass shoots disappeared in experiments after approximately $3 \mathrm{wk}$ of severe light reductions that mimicked the red tide algal bloom (K.-S. Lee unpubl. data). Shoot densities of various seagrass species decreased significantly after shading treatments of about 1 mo (Longstaff \& Dennison 1999, Holmer \& Laursen 2002). Cabello-Pasini et al. (2002) reported that in situ underwater irradiance in eelgrass beds on the Pacific coast of Baja California was reduced to nearly zero for $>3 \mathrm{wk}$ because of winter storms. This prolonged period of light limitation promoted the rapid disappearance of the eelgrass pop- ulation from the area. In most cases, however, increasing water turbidity and seagrass decline caused by anthropogenic nutrient loading have occurred gradually over an extended period (Onuf 1996).

Non-structural carbohydrates can be used to meet the demands of respiration and plant growth when carbon demands exceed photosynthesis, whereas photosynthetic carbon accumulates as carbohydrate reserves in tissues when photosynthesis exceeds carbon demands (Dawes \& Guiry 1992, Lee \& Dunton 1997). Carbohydrate reserves in seagrass tissues, therefore, are critical for survival and re-growth during extended periods of light limitation, which induce a negative carbon balance (Genot et al. 1994, Rey \& Stephens 1996, Lee \& Dunton 1997). Sugar levels in the leaf tissues of eelgrass decreased to almost undetectable levels when incubated for $3 \mathrm{wk}$ in darkness (CabelloPasini et al. 2002). The severe light reduction for about 2 wk during the red tide algal bloom probably exhausted tissue carbohydrate reserves, which can be used for new leaf tissue production after the bloom event. Light saturation at 100 to $200 \mu \mathrm{mol}$ photons $\mathrm{m}^{-2}$ $\mathrm{s}^{-1}$ and a light-compensation point of 10 to $20 \mu \mathrm{mol}$ photons $\mathrm{m}^{-2} \mathrm{~s}^{-1}$ have been reported for photosynthesis of eelgrass (Dennison \& Alberte 1982, 1985, Dennison 1987, Zimmerman et al. 1994). Underwater PFDs at the study site never reached the light-saturation point during the bloom event. The average $H_{\text {comp }}$ (daily periods of light intensities exceeding the compensation point) based on $>I_{\mathrm{c}}$ values was only $2 \mathrm{~h}$ during the bloom event. Thus, the severe light reduction during the bloom induced conditions of negative carbon balance and, eventually, resulted in significant decline of the stored carbon in eelgrass tissues.

In addition to light limitation, the thick layer of mucus secreted onto the eelgrass bed by the red tide algal cysts directly reduced the survival of eelgrass shoots. The red tide alga Heterosigma akashiwo is one of the most noxious red-tide-causing algae that occur in the coastal waters of temperate and sub-tropical areas (Itakura et al. 1996, Twiner et al. 2001). Blooms of this species result in significant losses of fish and shellfish stocks. Cysts of $H$. akashiwo were found in the bottom sediments when the bloom decayed and were surrounded by mucilaginous materials, which originated from the vesicular array that underlies the plasma membrane (Itakura et al. 1996, Han et al. 2002). The mucilaginous materials from the red tide algal cysts covered the eelgrass bed in a layer about 0.3 to $1.0 \mathrm{~m}$ thick. Eelgrass shoots and benthic animals were suffocated under the mucus, and most eelgrass shoots 


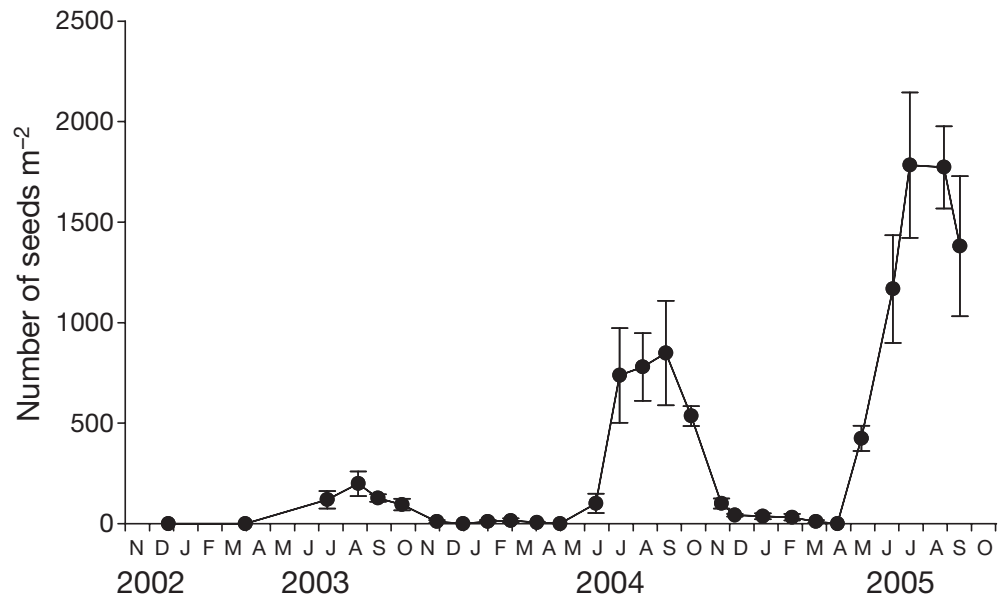

Fig. 9. Zostera marina. Seasonal changes of seed densities (mean $\pm \mathrm{SE}$ ) in the seed bank at the study site in Jindong Bay on the south coast of Korea from December 2002 to September 2005

Table 2. Zostera marina. Potential seed production (mean \pm SE) calculated from the reproductive shoot density, number of inflorescences per shoot, and number of seeds per inflorescence for each year from 2002 to 2005

\begin{tabular}{|ccccc|}
\hline Year & $\begin{array}{c}\text { Reproductive } \\
\text { shoot density } \\
\left(\text { shoots } \text { m }^{-2}\right)\end{array}$ & $\begin{array}{c}\text { No. } \\
\text { inflorescences } \\
\text { per shoot }\end{array}$ & $\begin{array}{c}\text { No. seeds per } \\
\text { inflorescence }\end{array}$ & $\begin{array}{c}\text { Potential seed } \\
\text { production } \\
\text { (seeds m }\end{array}{ }^{-2}$ ) \\
\hline 2002 & $22.5 \pm 3.9$ & $25.2 \pm 1.8$ & $9.8 \pm 0.3$ & 5544 \\
2003 & $10.2 \pm 6.1$ & $12.4 \pm 1.8$ & $10.0 \pm 0.3$ & 1265 \\
2004 & $44.9 \pm 9.7$ & $35.0 \pm 4.1$ & $10.1 \pm 0.2$ & 15872 \\
2005 & $103.4 \pm 14.4$ & $25.4 \pm 1.4$ & $9.7 \pm 0.2$ & 25476 \\
\hline
\end{tabular}

2003). When some shoots survive disturbance, recolonization probably occurs via vegetative reproduction. However, nearly all eelgrass shoots were killed by the algal bloom at this site. Thus, the initial eelgrass recolonization of this disturbed area had to occur through the germination of seeds in the sediments.

Rapid natural recolonization of seagrasses through seedling recruitment has been observed after destruction caused by various disturbances (Peterken \& Conacher 1997, Plus et al. 2003). A Zostera capricorni bed in Moreton Bay, Australia, recovered in $<1$ yr after intensive dugong grazing because of seedling establishment (Peterken \& Conacher 1997). Recolonization of Z. marina after destruction caused by an anoxic event in the French Mediterranean Sea also occurred via the germination of seeds in the sediments (Plus et al. 2003). Off Korea, the eelgrass shoot density in the disturbed area rapidly increased because of new shoot recruitment from seed germination, and the meadow then spread through vegetative expansion via rhizome elongation and branching leading to new shoots. During the first spring after the die-off, all eelgrass shoots were seedlings that developed from the seed bank, and no adult shoots were found at the site. Seedling density increased dramatically during the first winter after the die-off;

were killed by the direct suffocating effect of this mucilaginous material. Increased organic accumulation due to the death of benthic animals and the mucilaginous materials during the bloom event may also have contributed to eelgrass die-off through increases in oxygen demand, sulfides, and $\mathrm{NH}_{4}{ }^{+}$levels in the water column and/or sediments (Carlson et al. 1994, van Katwijk et al. 1997).

\section{Recolonization of the disturbed eelgrass bed}

Recolonization of seagrass beds following destruction caused by various disturbances has been reported in many seagrass species (Peterken \& Conacher 1997, Plus et al. 2003, Rasheed 2004, Olesen et al. 2004, Bernard et al. 2005). Seagrass meadows are mainly maintained and expanded through asexual reproduction. New shoot production via clonal growth is a key component of space occupation by seagrasses, particularly during expansion or recolonization of disturbed meadows (Duarte \& Sand-Jensen 1990, Plus et al. thereafter, shoot density did not change greatly. The change in shoot density following the bloom event implies that nearly all shoots that appeared during the first year after die-off were produced by sexual reproduction through seedling recruitment from the seed bank, and that vegetative reproduction was limited during the first year of recolonization, although a few seedlings produced lateral shoots about 4 to 6 mo after germination.

The relative contribution of sexual and asexual reproduction to the maintenance and/or recovery of seagrass populations vary with the colonization phase (Plus et al. 2003, Greve et al. 2005). A 2-step seagrass recolonization process has been reported in disturbed areas (Duarte \& Sand-Jensen 1990, Plus et al. 2003, Greve et al. 2005). During the initial phase of recolonization, shoot density usually increases via sexual reproduction through seedling recruitment, after which the seagrass meadow expands via asexual reproduction through lateral shoot production. Before the red-tide event, seedlings accounted for about $23 \%$ of the total shoot density in spring, when eelgrass cov- 
erage expands through clonal growth. Whereas all shoots observed at the site were seedlings in the first spring after the red-tide event, seedlings accounted for only $6 \%$ of all shoots in the spring of the second and third years, when the eelgrass bed had completely recovered from the effects of the algal bloom. These differences in the ratio of seedlings to adult shoots before and after the algal bloom suggest that sexual reproduction plays a major role in the initial recolonization of seagrass beds after die-off. However, asexual reproduction is the main mechanism increasing shoot density during periods of growth in undisturbed and completely recovered seagrass beds; seed banks in the sediment play a minor role in these beds in terms of recruitment of new shoots.

A large contribution of seedling recruitment to the revegetation of seagrass beds has also been observed in eelgrass populations with annual life cycles (Keddy 1987, Harrison 1993, Meling-López \& Ibarra-Obando 1999, Santamaría-Gallegos et al. 2000). Annual eelgrass plants in the southernmost populations on the coast of the Gulf of California die during the warm summer season, and the persistence of the meadows depends on seedling recruitment from the seed bank at the start of the growing season (Santamaría-Gallegos et al. 2000). We observed that eelgrass revegetation during the first year after die-off resulted from seedling growth alone, as occurs in annual eelgrass populations. However, in the second year after die-off, once the eelgrass bed was completely re-established, an increase in shoot density at the start of the growing season was mainly a result of vegetative ramification from existing rhizomes. The eelgrass population then exhibited perennial growth habits following re-establishment of the bed.

\section{Seed bank development and seedling growth}

Eelgrass seedlings are vulnerable to environmental disturbance, and the growth and survival rates of seedlings are often low. A seedling survival rate of $<5 \%$ has been reported for eelgrass from several areas (Churchill 1983, Harrison 1993, Olesen \& Sand-Jensen 1994, Olesen 1999, Greve et al. 2005). Low seedling survival rates in eelgrass are usually observed within established eelgrass beds characterized by substantial shading. Seedling survival rates in bare areas without shading are probably much higher than those in seagrass beds with high shoot densities. We found that almost all eelgrass seedlings that germinated after the bloom event survived the growing season in the first year of recolonization. Such high seedling survival rates have also been reported in an eelgrass bed destroyed by an anoxic event (Plus et al. 2003). In both cases, high seedling survival rates occurred in disturbed areas with few adult eelgrass shoots, and this high survival resulted in rapid recolonization via seedling growth over the course of $1 \mathrm{yr}$. These results suggest that seedling mortality is relatively low in areas with low shoot density, stressing the importance of sexual reproduction through seedling recruitment in the recolonization of seagrass beds after major disturbances.

The rapid growth of eelgrass seedlings also contributed to rapid eelgrass recolonization at the study site. Seedling size increased exponentially in spring and reached that of adult plants in early summer. Because of the low mortality and rapid growth of eelgrass seedlings, the standing stock of eelgrass in the disturbed area had nearly recovered to levels recorded before the bloom event by early summer of the first year of recolonization. Rapid growth of eelgrass seedlings also has been observed in areas of dieback caused by anoxia in a Danish estuary (Greve et al. 2005); these seedlings grew to a relatively stable size within about 3.5 mo.

The amount of seeds in the seed bank varies temporally depending on seed release, germination, and seed predation (Hootsmans et al. 1987, Harrison 1993, Fishman \& Orth 1996, Nakaoka 2002). Eelgrass seeds in the seed bank begin to germinate in fall; germination continues throughout the spring, with maximum germination rates in winter and early spring (Orth \& Moore 1983b). At our study site, seasonal changes in seed density in the seed bank reflected periods of seed release and germination. The amount of seeds in the seed bank, which was monitored monthly for $>2 \mathrm{yr}$ after the bloom event, rapidly increased to a maximum after periods of seed release and decreased to nearly zero after periods of seed germination. Because all eelgrass shoots that occurred during the first year of recolonization were seedlings $<1$ yr of age, number of inflorescences per shoot were distinctly lower in 2003 than in 2002, i.e. before the bloom, and, in 2004 and 2005 , i.e. when the eelgrass bed had reestablished. Thus, seed production in 2003 was significantly lower than in 2002, 2004, and 2005; this was reflected in the number of seeds in the seed bank.

However, seed density in the seed bank was significantly lower than calculated potential seed production, results similar to the actual and potential values reported for other eelgrass beds (Hootsmans et al. 1987, Santamaría-Gallegos et al. 2000). About $16 \%$ of the seeds produced in 2003 contributed to seed bank development. However, in 2004 and 2005, when the number of seeds produced was 10 to 20 times higher than in 2003, about 5 to $7 \%$ of the produced seeds remained in the seed bank. Large numbers of seeds produced at the site probably dispersed to unvege- 
tated areas and/or were consumed by seed predators (Wigand \& Churchill 1988, Fishman \& Orth 1996, Nakaoka 2002). Only a small portion of the eelgrass seeds in seed banks usually develops successfully into adult shoots (Harrison 1993, Olsen 1999). We found that 2 to $6 \%$ of the seeds in the seed bank developed into seedlings in 2004 and 2005, when the disturbed eelgrass bed had completely recolonized and shoot density was high. However, in 2003, after all adult shoots had died off, many more seedlings were found, and nearly all established successfully. These interannual differences in the rates of seed germination and seedling establishment suggest that germination rates and seedling establishment are significantly affected by in situ shoot density.

In conclusion, a harmful algal bloom caused by high densities of the alga Heterosigma akashiwo occurred at an eelgrass bed on the coast of Korea, where monitoring of the eelgrass bed was in progress; the bloom lasted for about $2 \mathrm{wk}$. All eelgrass shoots disappeared due to both severe light reductions during the bloom and suffocation by the thick layer of the mucilaginous materials secreted by the cysts of the red tide alga. The initial eelgrass recolonization of the denuded area occurred through seedling recruitment from the seed bank. Seedlings germinated after the bloom event showed high survival and growth rates, and thus the disturbed bed rapidly recovered to levels recorded before the bloom event. This study provided valuable information towards understanding the seagrass dieoff process caused by harmful algal blooms and the relative contribution of sexual and asexual reproduction to the recovery and maintenance of seagrass populations.

Acknowledgements. We thank D. W. Kang and M.-J. Park for their field assistance and laboratory support. Three anonymous reviewers provided useful comments on earlier versions of the manuscript. This work was supported by the Ministry of Maritime Affairs \& Fisheries of Korea (Grant No. 20040053 and the project 'Reduction of greenhouse gas using seaweeds').

\section{LITERATURE CITED}

Bernard G, Bonhomme P, Boudouresque CF (2005) Recovery of the seagrass Zostera marina in a disturbed Mediterranean lagoon (Etang de Berre, Bouches-du-Rhône, southern France). Hydrobiologia 539:157-161

Cabello-Pasini A, Lara-Turrent C, Zimmerman RC (2002) Effect of storms on photosynthesis, carbohydrate content and survival of eelgrass populations from a coastal lagoon and the adjacent open ocean. Aquat Bot 74:149-164

Cambridge ML, McComb AJ (1984) The loss of seagrasses in Cockburn Sound, Western Australia. I. The time course and magnitude of seagrass decline in relation to industrial development. Aquat Bot 20:229-243
Carlson PR, Yarbro LA, Barber TR (1994) Relationship of sediment sulfide to mortality of Thalassia testudinum in Florida Bay. Bull Mar Sci 54:733-746

Churchill AC (1983) Field studies on seed germination and seedling development in Zostera marina L. Aquat Bot 16: $21-29$

Dawes CJ, Guiry MD (1992) Proximate constituents in the seagrasses Zostera marina and Z. noltii in Ireland: seasonal changes and the effect of blade removal. Mar Biol $13: 307-315$

Dennison WC (1987) Effects of light on seagrass photosynthesis, growth and depth distribution. Aquat Bot 27:15-26

Dennison WC, Alberte RS (1982) Photosynthetic responses of Zostera marina L. (eelgrass) to in situ manipulations of light intensity. Oecologia 55:137-144

Dennison WC, Alberte RS (1985) Role of daily light period in the depth distribution of Zostera marina (eelgrass). Mar Ecol Prog Ser 25:51-61

Dennison WC, Orth RJ, Moore KA, Stevenson JC, Carter V, Kollar S, Bergstrom PW, Batiuk RA (1993) Assessing water quality with submersed aquatic vegetation. BioScience 43 : 86-94

Duarte CM, Sand-Jensen K (1990) Seagrass colonization, biomass development and shoot demography in Cymodocea nodosa patches. Mar Ecol Prog Ser 67:97-103

Fishman JR, Orth RJ (1996) Effects of predation on Zostera marina L. seed abundance. J Exp Mar Biol Ecol 198:11-26

Genot I, Caye G, Meinesz A, Orlandini M (1994) Role of chlorophyll and carbohydrate contents in survival of Posidonia oceanica cuttings transplanted to different depths. Mar Biol 119:23-29

Goldsborough WJ, Kemp WM (1988) Light responses of a submerged macrophyte: implications for survival in turbid tidal waters. Ecology 69:1775-1786

Greve TM, Krause-Jensen D, Rasmussen MB, Christensen PB (2005) Means of rapid eelgrass (Zostera marina L.) recolonization in former dieback areas. Aquat Bot 82:143-156

Han MS, Kim YP, Cattolico RA (2002) Heterosigma akashiwo (Raphidophyceae) resting cell formation in batch culture: stain identity versus physiological response. J Phycol 38: 304-317

Harrison PG (1993) Variations in demography of Zostera marina and $Z$. noltii on an intertidal gradient. Aquat Bot 45:63-77

Holmer M, Laursen L (2002) Effect of shading of Zostera marina (eelgrass) on sulfur cycling in sediments with constrasting organic matter and sulfide pools. J Exp Mar Biol Ecol 270:25-37

Hootsmans MJM, Vermaat JE, van Vierssen W (1987) Seedbank development, germination and early seedling survival of two seagrass species from the Netherlands: Zostera marina L. and Zostera noltii Hornem. Aquat Bot 28:275-285

Inglis GJ (2000) Disturbance-related heterogeneity in the seed bank of a marine angiosperm. J Ecol 88:88-99

Itakura S, Nagasaki K, Yamaguchi M, Imai I (1996) Cyst formation in the red tide flagellate Heterosigma akashiwo (Raphidophyceae). J Plankton Res 18:1975-1979

Keddy CJ (1987) Reproduction of annual eelgrass: variation among habitats and comparison with perennial eelgrass (Zostera marina L.). Aquat Bot 27:243-256

Kim HG (2005) Harmful algal blooms in the sea. Dasom Publishers, Busan

Kim HG, Lee PY, Lee SG, Cho YC, Choi HG (2000) Handbook on oceanography, marine environment and harmful algal blooms. National Fisheries Research \& Development Institute, Busan 
Lee KS, Dunton KH (1997) Effects of in situ light reduction on the maintenance, growth and partitioning of carbon resources in Thalassia testudinum. J Exp Mar Biol Ecol 210:53-73

Lee KS, Lee SY (2003) The seagrasses of the Republic of Korea. In: Green EP, Short FT, Spalding MD (eds) World atlas of seagrasses: present status and future conservation. University of California Press, Berkeley, CA

Lee KS, Park SR, Kim JB (2005) Production dynamics of the eelgrass Zostera marina in two bay systems on the south coast of the Korean peninsula. Mar Biol 147:1091-1108

Longstaff BJ, Dennison WC (1999) Seagrass survival during pulsed turbidity events: the effects of light deprivation on the seagrasses Halodule pinifolia and Halophila ovalis. Aquat Bot 65:105-121

Meling-López AE, Ibarra-Obando SE (1999) Annual life cycles of two Zostera marina L. populations in the Gulf of California: contrasts in seasonality and reproductive effort. Aquat Bot 65:59-69

Nakaoka M (2002) Predation on seeds of seagrasses Zostera marina and Zostera caulescens by a tanaid crustacean Zeuxo sp. Aquat Bot 72:99-106

Olesen B (1999) Reproduction in Danish eelgrass (Zostera marina L.) stands: size-dependence and biomass partitioning. Aquat Bot 65:209-219

Olesen B, Sand-Jensen K (1994) Patch dynamics of eelgrass Zostera marina. Mar Ecol Prog Ser 106:147-156

Olesen B, Marba N, Duarte CM, Savela RS, Fortes MD (2004) Recolonization dynamics in a mixed seagrass meadow: the role of clonal versus sexual processes. Estuaries 27: $770-780$

Onuf CP (1994) Seagrasses, dredging and light in Laguna Madre, Texas, USA. Estuar Coast Shelf Sci 39:75-91

Onuf CP (1996) Seagrass responses to long-term light reduction by brown tide in upper Laguna Madre, Texas: distribution and biomass patterns. Mar Ecol Prog Ser 138: $219-231$

Orth RJ, Moore KA (1983a) Chesapeake Bay: an unprecedented decline in submerged aquatic vegetation. Science 222:51-53

Orth RJ, Moore KA (1983b) Seed germination and seedling growth of Zostera marina L. (eelgrass) in the Chesapeake Bay. Aquat Bot 15:117-131

Parsons TR, Maita Y, Lalli CM (1984) A manual of chemical and biological methods for seawater analysis. Pergamon Press, New York

Editorial responsibility: Otto Kinne (Editor-in-Chief), Oldendorf/Luhe, Germany
Peterken CJ, Conacher CA (1997) Seed germination and recolonization of Zostera capricorni after grazing by dugongs. Aquat Bot 59:333-340

Plus M, Deslous-Paoli JM, Dagault F (2003) Seagrass (Zostera marina L.) bed recolonization after anoxia-induced full mortality. Aquat Bot 77:121-134

Rasheed MA (2004) Recovery and succession in a multi-species tropical seagrass meadow following experimental disturbance: the role of sexual and asexual reproduction. J Exp Mar Biol Ecol 310:13-45

Rey JR, Stephens FC (1996) Effects of shading and rhizome isolation on soluble carbohydrate levels in blades and rhizomes of the seagrass Syringodium filiforme. Gulf Mex Sci $14: 47-54$

Ruiz JM, Romero J (2001) Effects of in situ experimental shading on the Mediterranean seagrass Posidonia oceanica. Mar Ecol Prog Ser 215:107-120

Santamaría-Gallegos NA, Sánchez-Lizaso JL, Félix-Pico EF (2000) Phenology and growth cycle of annual subtidal eelgrass in a subtropical locality. Aquat Bot 66:329-339

Shin H, Choi HK (1998) Taxonomy and distribution of Zostera (Zosteraceae) in eastern Asia, with special reference to Korea. Aquat Bot 60:49-66

Short FT, Burdick DM (1996) Quantifying eelgrass habitat loss in relation to housing development and nitrogen loading in Waquoit Bay, Massachusetts. Estuaries 19: 730-739

Short FT, Wyllie-Echeverria S (1996) Natural and humaninduced disturbance of seagrasses. Environ Conserv 23: $17-27$

Tomlinson PB (1974) Vegetative morphology and meristem dependence - the foundation of productivity in seagrass. Aquaculture 4:107-130

Twiner MJ, Dixon SJ, Trick CG (2001) Toxic effects of Heterosigma akashiwo do not appear to be mediated by hydrogen peroxide. Limnol Oceanogr 46:1400-1405

van Katwijk MM, Vergeer LHT, Schmitz GHW, Roelofs JGM (1997) Ammonium toxicity in eelgrass Zostera marina. Mar Ecol Prog Ser 157:159-173

Wigand C, Churchill AC (1988) Laboratory studies on eelgrass seed and seedling predation. Estuaries 11: 180-183

Zimmerman RC, Cabello-Pasini A, Alberte RS (1994) Modeling daily production of aquatic macrophytes from irradiance measurements: a comparative analysis. Mar Ecol Prog Ser 114:185-196

Submitted: August 2, 2006; Accepted: February 26, 2007 Proofs received from author(s): July 14, 2007 